\title{
In the context of a daycare center: nursing and their representations of child care as an educational act
}

\author{
NO CONTEXTO DA CRECHE: A ENFERMAGEM E SUAS REPRESENTAÇÕES DO \\ CUIDADO À CRIANÇA COMO ATO EDUCATIVO
}

\section{EN EL CONTEXTO DE LA GUARDERÍA: ENFERMERÍA Y SUS REPRESENTACIONES DE CUIDADO INFANTIL COMO UN ACTO EDUCATIVO}

\author{
Vicente Sarubbi Jr. ${ }^{1}$, Camila Junqueira Muylaert ${ }^{2}$, Sophia Motta Gallo ${ }^{3}$, Paulo Rogério Gallo ${ }^{4}$
}

\begin{abstract}
This study sought to analyze the representations present in the speech of professional technical staff working with children in the daycare centres of USP. The study covered all the university's daycare units. Eight nursing professionals underwent a semi-structured interview. The interviews were recorded and transcribed in their entirety and the content of the discourse subjected to thematic-categorical analysis. The categories were transformed into variables and processed by the Classification Hiérarchique Classificatoire et Cohésitive $\left(\mathrm{CHIC}^{\circledR}\right)$ software, which generated a hierarchical similarity tree. The results indicate that actions to promote health are educational and transformative, and that through them health care gains new meaning through contextualized conceptions in the field of child education. We conclude that professionals attribute new meanings to their practices in the health care environment of daycare centres as their thinking shifts from the logic of the biomedical field to a logic of educational care. Thus the professional staff perceive themselves as being challenged to establish an interaction with the children in terms of their activities related to the promotion of health in educational terms.
\end{abstract}

\section{RESUMO}

O estudo teve como objetivo analisar as representações sociais dos profissionais das equipes técnicas que trabalham nas creches da Universidade de São Paulo (USP). Foram entrevistados oito profissionais da área de enfermagem com o uso de um roteiro semiestruturado. As entrevistas foram gravadas e transcritas na íntegra e o conteúdo submetido à análise de conteúdo temático-categorial. As categorias foram transformadas em variáveis, processadas pelo software Classification Hiérarchique Classificatoire et Cohésitive $\left(\mathrm{CHIC}^{\circledR}\right)$ e analisadas pela árvore hierárquica de similaridade (cluster multinível). Os resultados indicam que as ações acerca da promoção à saúde são relatadas como educativas e transformadoras, em que o cuidado em saúde ganha novos significados por meio de concepções contextualizadas no campo da educação infantil. Conclui-se que os profissionais ressignificam suas práticas de cuidado em saúde no ambiente das creches em que as representações transitam da lógica biomédica do cuidar para uma lógica educativa do cuidado. Neste sentido, se percebem desafiados na interação que estabelecem com as crianças acerca de sua atuação vinculada à promoção da saúde e ao ato de educar.

\section{RESUMEN}

El objetivo de la investigación estudio fue analizar las representaciones sociales de los técnicos profesionales que trabajan en los centro de atención infantil de la Universidad de São Paulo (USP). Ocho profesionales de enfermería fueron entrevistados mediante un semi-estructurada guión. Las entrevistas fueron grabadas y transcritas y sometidas al análisis de contenido temático-categorial. Las categorías se transformaron en variables procesadas por hiérarchique Classificatoire et Cohesiva software Clasificación ( $\mathrm{CHIC}^{\circledR}$ ) y analizados por similitud árbol jerárquico (clúster de múltiples niveles). Los resultados indican que las acciones sobre promoción de la salud se reportan como educativo y transformador, en que la atención de la salud adquiere nuevos significados a través de concepciones contextualizadas en el campo de la educación infantil. Llegamos a la conclusión de que los profesionales atribuyen nuevos significados a sus prácticas en el ámbito sanitario de los centro de atención infantil sus representaciones turnos desde la lógica del campo de la biomedicina a la lógica de la atención educativa. En este sentido, los propios que perciben al ser desafiados a establecerse una interacción con los niños en términos de sus actividades relacionadas con la promoción de la salud y en un acto educativo.

\author{
DESCRITORES \\ Enfermagem \\ Creches \\ Cuidado a criança \\ Educação em saúde
}

\section{DESCRIPTORES \\ Enfermería \\ Jardines Infantiles \\ Cuidado del Niño \\ Educación en Salud}

\footnotetext{
${ }^{1}$ Psychologist. Master of Science. Department of Maternal and Child Health, Faculty of Public Health, University of Sao Paulo, Sao Paulo, Brazil. ${ }^{2}$ Psychologist. Master of Science. Department of Maternal and Child Health, Faculty of Public Health, University of Sao Paulo, Sao Paulo, Brazil. ${ }^{3}$ Psychologist. Doutora of Science. Department of Maternal and Child Health, Faculty of Public Health, University of Sao Paulo, Brazil. Post-doctor of Health Science. Faculty of Medicine of ABC. ${ }^{4}$ Pediatrician. Associate Professor. Department of Maternal and Child Health, Faculty of Public Health, University of Sao Paulo, Sao Paulo, Brazil.
} 


\section{INTRODUCTION}

From 1966, under the coordination of the Secretariat of Social Welfare, the creation of Daycare centers have been prioritized in Sao Paulo(1). The service was expanded to cover the population of families in need ceasing to be a specific privilege of working mothers ${ }^{(2)}$.

With the increased demand, the service started being done precariously, among other reasons for the increase in the number of children per class, so the quality of care offered by child daycare remained as a second plan $^{(3)}$. We started to identify poor conditions of the buildings and equipment in the institutions as well as the lack of pedagogical proposals and the difficulty in communicating with families $^{(4)}$.

In 1984 the Ministry of Health established the Program for Integrality of Child Health Care (PICHC), focused on preventive health activities such as immunization, breastfeeding, disease control and monitoring of child growth and development ${ }^{(5)}$.

In 1996, trying to assist more families, given our political and social scenario, the Guidelines of the National Policy of Education made daycare centers and pre-schools part of the first stage of the Childhood Education - these being a right of the child, family and duty of the state ${ }^{(6)}$.

Childcare centers now have the responsibility to provide the child's education and the provision of basic health care, being also responsible for their physical and emotional safety, including care for hygiene, feeding, affection and education ${ }^{(7)}$. As a space for childhood education, these spaces have assumed the commitment to mediate the interaction of the child with the collective environment and with whom assists in the pursuit of promoting the development of creative and autonomous individuals ${ }^{(8)}$.

New proposals have been held, inviting the child to be a participant in an experience that occurs in the interaction with the community to which she/he belongs, with the educational institution as a mediator of the dialogue, and providing a new look for these children about their surroundings ${ }^{(9)}$.

The proposed institutional care of children as subjects of rights, according to constitutional principles ${ }^{(10)}$ and the standards from the secretary of education ${ }^{(11)}$, resulted in a change of institutional routines regarding the care and repositioning ${ }^{(12)}$ of the professionals who are in direct contact with children. The professional practice related to childhood education environment became referred to as a support for the promotion of child health ${ }^{(13)}$.

By taking responsibility for emotional and physical custody of the child full time and taking the challenge to match the advances of laws and programs for Childhood Education, the daycare environment migrated from wel- fare rationale for prioritizing the stimulus relations of interaction and care, whose experiences offered to children meet a new institutionalized identity ${ }^{(14)}$.

As a promising space for the incorporation of habitus in daily living, daycare centers have become an opportunity for each child, to the extent that they experienced a period of significant learning, to develop self-care and care for the other ${ }^{(15,16)}$. Thus, the care of the child, in his/ her integrality, involves challenges such as providing safe and appropriate environment, the permanent supervision of the work and the continuing education of professionals who work in daycare centers ${ }^{(17)}$. In this context, the field of health and education must dialogue on the interface of knowledge that guides the work of these professionals, but the performance of a joint work is still challenge presented in the form of the instrumental-disciplinary training for each field of work ${ }^{(18,19)}$.

Researches in the Nursing area have shown important reference about the care present in the interface health-education in the school environment, when investigated different elements such as adaptation of the child and family to the institution, nutrition, sleep and rest, prevention of accidents and diseases, health promotion, as well as monitoring of growth and physical and emotional development, contextualizing them in a proposal for child care in Brazilian daycares centers and preschools $^{(5)}$.

Thus, reflecting on how the practices of health promotion are developed from the perspective of care, we highlighted discussions about the diversity of health social actors and dialogue able to recognize the different realities imposed by various aspects that give meaning to human existence $^{(20)}$. As a focus of reflections, care has been assisting in the planning and development of new interventions aimed at the treatment of children in their integrality ${ }^{(5,21)}$. The present study aimed to investigate the conceptions of childcare by nursing professionals working in daycare center, from their representations.

\section{METHOD}

Cross sectional study of descriptive and qualitative approach without a random sampling. We present the partial results of a research conducted with the technical teams about child care in daycare centers of the University of Sao Paulo - USP(22). The study population represented a total $(n=8)$ of eight nursing professionals in the five daycare centers, composed of women aged between 36 and 57 years, being four technicians and a professional with a degree in nursing.

The five daycare centers work in full-time assisting children, children of faculty members, students and other staff linked to the USP community (table 1). 
Table 1 - Distribution of assisted children in daycare centers at USP

\begin{tabular}{|c|c|c|c|c|c|}
\hline \multirow[t]{2}{*}{ Infrastructure } & \multicolumn{5}{|c|}{ Unidades de creche segundo as cidades em que se localizam os campi da USP* } \\
\hline & Sao Paulo1 & Sao Paulo2 & Sao Paulo3 & Ribeirao Preto & Sao Carlos \\
\hline Capacity & 200 & 100 & 55 & 140 & 90 \\
\hline
\end{tabular}

*Data provided by the Division of Daycare Centers of the current SSW - Superintendency of Social Work, University of Sao Paulo (October, 2011).

The reason for the creation of daycare centers at USP does not differ from other institutions of the country: to give support to mothers who are inserted in the workplace. However, as a support network that has the support of the University of Sao Paulo, these daycare centers have characteristics that positively differentiate the reality presented by most Brazilian daycare centers and preschools.

This makes the study initially limited to a dialogue with situations where there is a structured and active institution in the multidisciplinary team. Still, the reason for choosing the field of USP childcare centers was to investigate what are the elements present in a context that presents elements geared to meet the political-pedagogical projects of health promotion in the school environment and what this research could potentially contribute to other realities in the country.

Semi-structured interviews were conducted from a script previously subjected to pre-testing. The script integrated questions to identify the subject and aimed to contextualize the representations of professionals about the care of children in daycare centers. The time of the interviews, conducted individually, respected the free as- sociative content and availability that each professional could dedicate to the study.

The method used to analyze the transcribed data was thematic-categorical|(23-25), where the theme is understood as an unit of meaning that stands out of the text content. To systematize thematic analysis, different steps of content analysis of the research material were carried out: the step of pre-analysis (initial reading), the step of exploration of the material (coding and categorizing the data transformed into units of meaning that describe the relevant characteristics the content of the analyzed body) and the step of analysis of results ${ }^{(23)}$.

The units of meaning were coded and processed with $\mathrm{CHIC}^{\circledR}$ software (Classification Hiérarchique Classificatoire et Cohésitive), version 4.1, which provides quality indexes of association and represents the structure of the variables obtained through mathematical analyzes ${ }^{(26)}$.

For this study, the analysis of Hierarchical Classification of Similarity (Table 2) was used. It describes the classes and subclasses prioritized according to the degree of association (similarity) between the variables analyzed $(\geq 0.50 \text { and } \leq 1.0)^{[27]}$.

Table 2 - Thematic categories processed by the CHIC® software

\begin{tabular}{|c|c|c|c|}
\hline \multirow{2}{*}{ Thematic categories } & \multicolumn{3}{|c|}{ Categorization by similarity index $\mathrm{CHIC}^{\circledR}$ software. } \\
\hline & Variable (thematic unit) & Similarity & $\geq 0,50$ and $\leq 1,0$ \\
\hline \multirow{4}{*}{$\begin{array}{l}\text { Health logic expanded and } \\
\text { dimensioned by the logic of } \\
\text { education }\end{array}$} & prevention actions & \multirow{2}{*}{\multicolumn{2}{|c|}{0,71}} \\
\hline & learning in the context of early childhood education & & \\
\hline & $\begin{array}{l}\text { Focus towards health } \\
\text { value of having a team of professionals }\end{array}$ & \multicolumn{2}{|r|}{0,65} \\
\hline & Being available to care for the child. & \multicolumn{2}{|r|}{0,50} \\
\hline \multirow{5}{*}{$\begin{array}{l}\text { Challenges of teaching and } \\
\text { learning practices of health care in } \\
\text { the school environment }\end{array}$} & $\begin{array}{l}\text { Challenges of knowledge in the school environment. } \\
\text { Care for the Children in their integrality. }\end{array}$ & \multicolumn{2}{|r|}{0,74} \\
\hline & Projects related to health promotion. & \multirow{3}{*}{\multicolumn{2}{|c|}{0,79}} \\
\hline & Physical symptoms as an expression of affection. & & \\
\hline & Responsibility of the professional to care for the child integrally. & & \\
\hline & $\begin{array}{l}\text { Caring and learning in relation to the child. } \\
\text { Creating an environment that is transformative. }\end{array}$ & \multicolumn{2}{|r|}{0,88} \\
\hline \multirow{3}{*}{ The care that educates } & $\begin{array}{l}\text { Binomial education-care } \\
\text { Attention to affection }\end{array}$ & \multicolumn{2}{|r|}{0,71} \\
\hline & $\begin{array}{l}\text { The care that promotes autonomy } \\
\text { Learning about caring in the relationship established with the child. }\end{array}$ & \multicolumn{2}{|r|}{0,88} \\
\hline & $\begin{array}{l}\text { Professional actions related to health promotion. } \\
\text { Caring for daycare environment. }\end{array}$ & \multicolumn{2}{|r|}{0,69} \\
\hline
\end{tabular}


The theoretical framework adopted for data discussion was the Theory of Social Representations ${ }^{(28,29)}$, the concept of habitus in Bourdieu ${ }^{(30)}$ and Freire's pedagogy of autonomy ${ }^{(31)}$.

The research project was submitted to the Ethics Committee of the School of Public Health, University of Sao Paulo, research protocol No. 2245. The procedures taken in the study met the criteria of the Ethics in Human Research according to the current resolution, no. 196/96, by the National Health Council.

\section{RESULTS AND DISCUSSION}

\section{A. When the logic of education resizes the logic of health care.}

When they are inserted in daycare centers, nursing professionals report the challenge to resize their knowledge in order to rethink the care actions.

"It's what I wanted, and new things came and many that I had not imagined that existed, things I would have to face, because I was more involved with health, hospital, and here is very different, here it is health with education. It is quite different."(SUJ1)

Participants point out that when performing work connected with education in health, they are working greatly as an educator in the knowledge interface between the fields of health and education.

"In the COSEAS manual [SSW] that we're writing, how do I teach hygiene educating in a daycare? How do I medicate inside the daycare, but knowing that this action has to be educational and transformative."(SUJ5)

Invited to play a mediation link that content related to health can advance to an interface of educational knowledge, health professionals tend to find a tension caused by the unfamiliar ${ }^{(28)}$. Characterized by memory and by the predominance of established positions, the process of familiarizing the unknown triggers general mechanisms such as categorization, classification, designation and procedures by which to appropriate the new in order to explain it ${ }^{(32)}$.

To Ceccim $^{(33)}$ it is overwhelming that health professionals learn to work everyday that are shared and paradigmatically transformers, since the inheritance of values related to culture and the practices themselves also inherited convey the perceived reality, determining the actions of individuals historically connected to it. Each culture uses instruments to transform the represented objectified reality, assigning relations intended, ends and means ${ }^{(28)}$.

Silva and Bolsanello ${ }^{(34)}$ argue that the organization of the daycare center should come from different needs related to the development of the child and not for its adaptation to the needs for which the daycare is organized.
Contextualizing the production of care and pedagogical production. Thus, nursing professionals can play an important role along with the pedagogical projects if they can achieve a dialogic communication beyond the reproduction of informational characteristic model of health ${ }^{(19,33)}$.

When participants perform work related to education, it is clear and we highlight their statements refer acting greatly as educators who work not only in the care of children, but also as reference of knowledge to other professionals that add staff. This new logic creates a rupture ${ }^{(9,19)}$ in which the professional led to resize their role on care practices.

\begin{abstract}
"Everything here is related to childhood education, starting with child health. In child health we work with theater, puppets, videos, conversation wheel, then both work in childhood education as the health, disciplines are related."(SUJ3)
\end{abstract}

"Our work is this health promotion, participating in projects with educators, daycare meetings. The direction and coordination also help. The work we do in relation to hygiene, dental treatment. Doing this will work with the children. And promoting children's learning." (SUJ8)

Bourdieu $^{(30)}$ states that the habitus, as a system of rules for practice, guide the agents to behave in a certain way, given the circumstances experienced. He also claims that even what is more codified, has beyond the purpose of the practice, not having the habitus actions generated by the regularity of a legislative principle, but a confrontation oriented by practice, which is constantly renewed, flowing, although the particular transgressions.

What actually is possible to find in the statement of technicians when they are challenged by learning in establishing an interaction with a child:

"The child teaches a lot to you. There is no such a thing like "I do not know". If you don't have an immediate answer you have to seek for one because they will ask you again

(...). Now I have a new horizon to offer for them."(SUJ3)

In this sense, social representations, arising from other chronological periods, endowed with historicity and objectifications, which tend to generate stability and appropriation given the reality that suffer the tensions of content reappropriation generated by new contexts of production and processing of meanings ${ }^{(28,35)}$.

The values inherited by the health communication, operationalized by technicians in the field of health, arising from the assistance-curative care model ${ }^{(19)}$, express representations about "not caring" that emerged in the statements of professionals, which explains the different tensions between inherited critical hygienist model and a model that attempts to place the care as a link that might reframe health education environment in child$\operatorname{hood}^{(14)}$. 


\section{B. Between teaching and learning in the context of care: the education-health link.}

As pointed out in Moscovici and Jodelet ${ }^{(28,29)}$, it takes a work of constant reflection to be no loss of dialogue about the references that anchor the professional practices. Health education depends greatly on the exercise of permanent reflection of nursing professionals who think about (represent) on their care actions, so they are not reduced to a biologicist understanding of health ${ }^{(35)}$.

The importance of having a cohesive multidisciplinary team in a daycare center appears in the speech of professional nursing, as a place where they feel welcome to rethink given the challenge of a knowledge that is not enough to meet the different demands in service which aims the integrality of a child:

\begin{abstract}
"When you have a computer, book, principal, pedagogue, psychologist, you have colleagues who work with children ... out of the world out there, in here I have already started developing the best way I see things and the way to disseminate that for them." (SUJ3)
\end{abstract}

The statements of professionals reinforces the importance of reflecting how investments in improving the quality of school environment - physical infrastructure, educational materials, multidisciplinary team and continuing education - can substantially increase the critical repertoire of every professional who works in it as an educator.

In order to accomplish that, it becomes essential to reflect about what "are the necessary ruptures for the transformation of the work process in nursing, and its core technology - the care process - resulting in overcoming and changing concepts, habits, procedures, finally, representations and practices" ${ }^{35(p 844)}$, as well as understanding how professionals linked to the practice of education in health, feel invested in care given the institution to which they belong.

To Spink ${ }^{(36)}$, once elaborated in socially structured field, social representations are formed from a social imprinting, whereby admitting the diverse and contradictory implied in the flow of social discourse does not mean giving up consensually that supports the assumptions. Thus, it is not about giving up health knowledge by the professional, but dialogue as to the use of knowledge the possibility of education that gives children a chance to develop autonomy for healthier choices without losing sight of the context in which they live.

The daycare center as a space for the formation of habitus and promotion of biological, mental and social health ${ }^{(15,30)}$ can provide both health professionals a new look at the community as providing children a new look to their surroundings to dialogue with their realities ${ }^{(9)}$. These actions, for Freire ${ }^{(31)}$, highlight the care of children while contextualized to what proposes educational practices by libertarian and autonomous process of making an ethical being with competencies about themselves.
For nursing professionals, health care, when thinking about it as a learning experience, is reported through the proposed activities on what child care is, it recognizes the importance of their physical and emotional uniqueness amidst the environment which faces meet the collective:

\footnotetext{
"The way a teacher who was helping me ... In cuddling the child rested on her chest and she began a song ... and even the child with fever, crying, she started, you know, with the little eyes closing ... I would take a picture of it, I would take a picture today. I'm sorry, but she is a person I deeply consider ...I'm [emotional] ... She sang the "pintinho amarelinho"1... After bathing [the child] and the fever was gone. When I went there to see the little girl, she was well." (SUJ3)
}

In this sense, the child care meets the proposal to win, as stated by Bianchi and Knopp ${ }^{[37]}$ a new epistemic field of understanding that is education, "making emerge social representations that directly influence the subject-subject and subject-object relations and, consequently, the educational practices, while social and communicative interactions with a formative intentionality" (37 p288).

\section{Health care as care that educates}

To Barbier ${ }^{(38)}$ studying the discursive interactions between individuals and groups indicates a broader way of thinking actions as a set of activities, with their meanings by individuals that seek to contextualize and transform the world and our own representations that underlie these actions.

Interdisciplinarity, as a pedagogical possibility of education and care, becomes relevant ongoing training and teamwork, where professionals can contribute in a jointly and contextualized way, to think the integrality of childcare ${ }^{(9)}$.

It becomes therefore crucial to consider that integrality of care should include, in addition to therapy, public sector policies and relations that guide state government and society to look at the subject-user within a logic of care that considers care in various dimensions of human beings ${ }^{(14)}$.

It is necessary to invest in constant research and improvement of the production of childcare logic in education in which the child also turns out to experience the source of tension generated by different interests and understandings of care aimed at them ${ }^{(39)}$.

Franco and Koifman ${ }^{(40)}$ consider educational practice as freedom as subjects as actors are able to understand and undertake changes in the objectified reality of care production process. At USP's daycare centers, professionals report that their experiences with children are perceived as transformative, from the experiences that they live with them and the bond that is established.

1 Pintinho amarelinho or Yellow little duck is a famous children's Brazilian song.
In the context of a daycare center: nursing and their representations of child care as an educational act Junior VC, Muylaert CJ, Gallo SM, Gallo PR 
"It is the expression of care in childhood education. When you are allowing the other person to perform actions that are so pleasurable that she/he needs to represent it many times in many ways. She/He reproduces that action so beautifully, it is a sign that the action is good and will stay. For me, care in childhood education, feeling cared for in early childhood education, is to have the ability to understand and perceive the other (...), I have enough to give to others. I received so I can give." (SUJ7)

According to Freire ${ }^{(31)}$, education can only be transformative for the student if this is also true for the educator, since education is a process that occurs in the interaction and the construction of values experienced in and through the learning relationship. As reinforced by Lira and da Silva ${ }^{(41)}$, care is to give encouragement and enabling "the manifestation of potential for more stable organization that tend to health (41p366)." When nursing professionals work in daycare centers as caregivers who educate, building representations that

\section{REFERENCES}

1. Augusto M. Comunidade infantil creche. Rio de Janeiro: Guanabara Koogan; 1985.

2. Motta MA. A creche: uma instituição a procura de identidade. Rev Bras Cresc Desenvolv Hum. 1996;6(1/2):14-18.

3. Correa BC. Considerações sobre qualidade na educação infantil. Cad Pesqui. 2003;(119):85-112.

4. Campos MM, Fullgraf J, Wiggers V. A qualidade da educação infantil brasileira: alguns resultados de pesquisa. Cad Pesqui. 2006; 36(127):87-128.

5. Brasil. Ministério da Saúde (BR). Assistência integral à saúde da criança: ações básicas. Brasília; 1984.

6. Brasil. LDB. Lei de Diretrizes e Bases da Educação Nacional. Lei no . 9.394, de 20 de dezembro de 1996. D.O.U. Brasília; 1996.

7. Rizzo G. Creche: organização, currículo, montagem e funcionamento. Rio de Janeiro: Bertrand Brasil; 2000.

8. Peters S, Cunha GG, Tizzei R. Uma experiência em psicologia, educação e comunidade. Psicol Soc. 2006;18(3):82-87.

9. Pereira B, K. S. S. Silva, R. P. Souza. Um cidadão não nasce grandão. Saúde Soc. 2009; 18, supl 2: 89-92.

10. Brasil. Constituição da República Federativa do Brasil. Diário Oficial da União, Brasília, 1988.

11. Brasil. LDB. Lei de Diretrizes e Bases da Educação Nacional. Lei no . 9.394, de 20 de dezembro de 1996. D.O.U., Brasília; 1996. help children to nominate potential new relationships with health.

"When I care I educate. There is no education without caring."(SUJ7)

\section{CONCLUSION}

Challenged to interact under a new logic of care present in the field of education, nursing professionals find initial difficulties in their practice which is anchored by the biomedical knowledge and are unable to meet the demands of care in childhood education environment.

Having a structured and cohesive team, and an institution that provides resources and encourages projects that link health promotion to the act of educating, allows nurses and nursing professional to reframe their practice, even in a field of paradigmatic tensions by proposing a new direction for health care that is inextricably intended to educate.

12. Bruder MB, Staff I, Kaminer EMM. Toddlers receiving early intervention in childcare centers. Topics Early Child Spec Educ. 1997;17(2):185.

13. Novaes MH. Psicologia da educação e prática profissional. Petrópolis: Vozes; 1992

14. Motta JA, da Silva PO, Marta CB, de Araújo BBM, Francisco MTR, Seabra Junior HC. O cuidado à criança na creche: integração entre saúde e educação. Rev. Enferm. UERJ. 2012; 20(esp2): 771-6.

15. Gomes VLO. A construção do feminino e do masculino no processo de cuidar de crianças em creches. Rev Eletrônica Enferm [Internet]. 2008; [acesso em 01 fev 2013]. 10 (1): 145-151. Disponível em: http://www.fen.ufg.br/revista/ v10/n1/pdf/v10n1a13.pdf

16. Faria ALG. Pequena infância, educação e gênero: subsídios para um estado da arte. Cad Pagu. 2006; (26):279-287.

17. Spada ACM. O cuidado e a educação no ambiente da creche: considerações acerca dos aspectos históricos e da formação de professores. Rev Cient Elet Pedag. [Internet]. 2007; [acesso em 01 fev 2013]. Ano V (10): 1-17. Disponível em: http:// www.revista.inf.br/pedagogia10/pages/artigos/edic10-anov-art01.pdf

18. Freire, P. Pedagogia do oprimido. Acesso pela biblioteca digital. Acervo da UFPB. 17a ed. Rio de Janeiro: Editora Paz e Terra; 1987.

19. Araújo IS, Cardoso JM. Comunicação em Saúde. Rio de Janeiro: Editora Fiocruz; 2007 
20. Erdmann AL, Andrade SR, Mello ALSF, Meirelles BHS. Gestão das práticas de saúde na perspectiva do cuidado complexo. Texto Contexto Enferm. 2006; 15(3): 483-91.

21. Pinho LB, Kantorski LP, Saeki T, Duarte MLC, Sousa JA. Integralidade no cuidado em saúde: um resgate de parte da produção científica da área. Rev. Eletr. Enf. [Internet]. 2007; [acesso em 01 fev 2013]. 9 (3): 835-46. Disponível em: http://www.fen.ufg.br/revista/v9/n3/v9n3a22.htm

22. Sarubbi VJr, Gallo PR. Social Representations regarding child-care at USP daycare centers. 1‥ ed. Saarbrucken: LAP LAMBERT, 2013.

23. Bardin L. Análise de conteúdo. Lisboa: Edições 70; 2007.

24. Campos CJG. Método de análise de conteúdo: ferramenta para a análise de dados qualitativos no campo da saúde. Rev Bras Enferm, Brasília. 2004; 57(5):611-4.

25. Oliveira DC. Análise de Conteúdo Temático-Categorial: uma proposta de sistematização. Rev. enferm. UERJ. 2008; 16 (4):569-76.

26. Couturier R, Gras R, editores. Introduction de variables supplémentaires dans une hiérarchie de classes et application à CHIC. In : Actes des 7. Rencontres de la Société Francophone de Classification, 1999 sept 15-17 ; Nancy, France. P.87-92.

27. Gras R, Almouloud SA. A implicação estatística usada como ferramenta em um exemplo de análise de dados multidimensionais. Educ Mat Pesqui. 2002; 4(2):75-88.

28. Moscovici S. Representações Sociais: investigações em psicologia social. Petrópolis: Vozes; 2009.

29. Jodelet D. A fecundidade na obra "A Psicanálise, sua imagem e seu público". In: Almeida AMO, Santos MFS, Trindade ZA, organizadores. Teoria das Representações Sociais: 50 anos. Brasília: Technopolitik; 2011. P. 199-223.

30. Bourdieu P. As coisas ditas. São Paulo: Brasiliense; 2004.
31. Freire P. Pedagogia da autonomia: saberes necessários à prática educativa. São Paulo: Paz e terra; 2011.

32. Sêga RA. O conceito de Representação Social nas obras de Denise Jodelet e Serge Moscovici. Anos 90. 2000; 8(13): 128-133.

33. Ceccim RB. Educação Permanente em Saúde: desafio ambicioso e necessário. Interface: Comunic, Saúde, Educ. 2005; 9(16): 161-77.

34. Silva CR, Bolsanello RA. No cotidiano das creches o cuidar e o educar caminham juntos. Interação em Psicologia. 2002; 6(1): 31-36.

35. Oliveira DC, Gomes AMT, Pontes AP M, Costa COM. Construção de um paradigma de cuidado de enfermagem pautado nas necessidades humanas e de saúde. Esc Anna Nery. 2011; 15 (4): 838-44.

36. Spink MJP. The Concept of Social Representations in Social Psychology. Cad. Saúde Públ. 1993; 9 (3): 300-308.

37. Bianchi C, Knopp MC. Educação, afetividade e representações sociais: uma relação triangular possível. In: Ornellas MLS, Oliveira MOM (organizadores). Educação, tecnologias e representações sociais. Salvador: Quarteto editora; 2007. P. 255-269.

38. Barbier J-M. Representações Sociais e Culturas de Ação. Cadernos de Pesquisa. 2010; 40(140): 351-378.

39. Maranhão DG, Sarti CA. Shared care: negotiations between families and professionals in a child day care center. Interface Comun Saúde Educ. 2007;11(22):257-70.

40. Franco CM, Koifman L. Produção do cuidado e produção pedagógica no planejamento participativo: uma interlocução com a Educação Permanente em Saúde. Interface: Comunicação Saúde Educação. 2010; 14 (34): 673-81.

41. Lira PS, da Silva MJP. O cuidado como uma Lei da Natureza: uma percepção integral do cuidar. Rev Esc Enferm USP 2008; 42(2): 363-70. 